understandably, anxious to avoid relapse once they have found a helpful therapy.

It is satisfying to read at last of a psychiatrist acknowledging the mood-elevating effect of oestrogens, and intriguing to observe the contrasting press coverage of their article which presents the increased "well-being" as a complication of dependence. We have published four randomised controlled trials showing that oestrogens improve postnatal ${ }^{1}$ and premenstrual depression ${ }^{2,3}$ and climacteric depression, ${ }^{4}$ the triad of potentially oestrogenresponsive affective disorders, without one letter of protest or support from psychiatrists. By contrast, the Bewleys' paper was reported on the front page of The Times, with the proclamation that "HRT can be as addictive as heroin"-a claim, incidentally, that the Bewleys do not make.

I have no doubt that many patients formerly distressed by insomnia, fatigue, and depression (and antidepressants or the occasional episode of electroconvulsive therapy) are dependent on the good health they achieve when on effective HRT. Is this really a cause for concern? There are certainly women who return for oestrogen implants more frequently than advised, and those who self-medicate with extra oestrogen tablets or oestradiol patches. These women have experienced a good response to the normal dose, and the problem is one of inappropriate expectations: "more" is regarded as "better". These women may need higher levels of oestradiol to obtain symptomatic relief, since many were originally treated for premenstrual syndrome (PMS) or climacteric depression. There may also be a greater incidence of psychiatric morbidity in this group. ${ }^{5}$

With implants symptoms return after 4-8 months, even though oestradiol levels are normal. ${ }^{6}$ An oestradiol implant removes symptoms whereas a placebo implant does not. ${ }^{7}$ These symptoms would thus seem to be a result of changes in oestradiol levels rather than absolute low levels. This is the basis of our hypothesis that the symptoms of PMS and postnatal depression are due to similar changes in sex hormones, and that the symptoms respond to an increase in plasma oestradiol levels and abolition of these fluctuations. As patients return with oestrogen-responsive symptoms for a repeat oestradiol implant, there is an increase of plasma oestradiol sometimes into the supraphysiological range ${ }^{8}$ equivalent to that found in the first month of pregnancy. It is a matter of debate whether this is dependence or merely the blood level necessary to control symptoms in patients who have been severely depressed.

The important question is whether these higher levels of oestradiol have a harmful end-organ response, especially on the breast. The only study comparing the incidence of breast cancer in women with oestrogen implants with that in women with lower oestradiol levels of oral oestrogens did not reveal any difference in risk. ${ }^{9}$ On the other hand, a major beneficial effect of higher oestradiol levels is the greater incremental increase in bone density obtained with implants, which is directly proportional to the oestradiol level achieved. ${ }^{10}$

I must protest that oestrogens are not "reputed to stop ageing". This may be the view of the tabloid press or even the mistaken belief of vulnerable women, but it is not a view held by any researcher or by even the most crusading zealot for HRT.

The Menopause Clinic,

Dulwich Hospital

London SE22 8PT, UK

JOHN STUDD

1. Henderson AF, Gregoire AJP, Kumar $R$, Sudd JWW The treatment of severe post-natal depression with oestradiol skin patches. Lancet 1991; 338: 816

2. Magos AL, Brincat $M$, Studd JWW. Treatment of the premenstrual syndrome by subcutaneous oestradiol implants and cyclical norethisterone: placebo controlled study. Br Med Y 1986; 292: 1629-33.

3. Watson NR, Studd JWW, Savvas M, Garnett TJ, Baber R. Treatment of severe pre-menstrual syndrome with oestradiol patches and cyclical norethisterone. Lancet 1989; 1 : 730-32.

4. Montgomery JC, Äppleby L, Brincat M, et al. Effects of oestrogen and testosterone implants on psychological disorders in the climacteric. Lancet 1987; i: 297-99.

5. Cardozo LD, Gibb DME, Tuck SM, Thom MN, Studd JWW. The effects of subcutaneous hormone during the climacteric. Maturitas 1984; 5: 177-84.

6. Brincat M, Magos A, Studd JWW, Carodozo LD, Wardle PD, Cooper D. Subcutaneous hormone implants for the control of climacteric symptoms. Lancet 1984 ; i: $16-18$.

. Gangar K, Cust M, Whitehead MI. Symptoms of oestrogen deficiency associated with supraphysiological plasma oestradiol concentrations in women with oestradiol implants. Br Med F 1989; 299: 601-02.
8. Studd JWW, Garnett T. Hormone implants and tachyphylaxıs. Br f Obstet Gynaecol 1991; 98: 502-03.

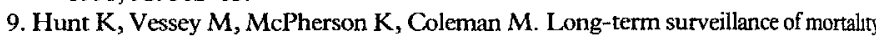
and cancer incidence in women recelving hormone replacement therapy $\mathrm{Br} f$ Obstet Gynaecol 1987; 94: 620-35.

10. Studd JWW, Savvas M, Fogelman I, Garnett T, Watson NR, Cooper D The relationshıp between plasma oestradiol and the increase in bone densiry post-menopausal women following therapy with oestradiol implants. Am $f$ Obste Gynecol 1990; 163: 1474-79.

\section{Norharman, a normal body constituent}

SIR,-Norharman is an aromatic unsubstituted $\beta$-carboline. This substance might be a natural ligand of benzodiazepine binding sites. ${ }^{1}$ Norharman also has comutagenic activity. ${ }^{2}$ A distinct class of high-affinity binding sites $\left(\mathrm{K}_{\mathrm{D}} 1.55 \mathrm{nmol} / \mathrm{l}\right)$ for norharman in rat brain has lately been demonstrated. ${ }^{3}$ Norharman has been found endogenously in rats by two groups of investigators. ${ }^{45}$ However, so far norharman has not been detected in human blood, probably because the procedure used was not sensitive enough. ${ }^{6}$ To increase the sensitivity of our norharman assay we modified both the sample clean-up and high performance liquid chromatography (HPLC) procedures. We now present evidence that norharman is a normal body constituent.

Plasma obtained from blood of 23 healthy donors was subjected to solid phase extraction on 'C-18 Seppack' (Millipore) columns. The main modifications of the procedure ${ }^{6}$ were: the extraction buffer contained no $\mathrm{NaClO}_{4}$ and the $\mathrm{pH}$ was $7 \cdot 7$ rather than $4 \cdot 0$ 7-15 ml plasma samples were applied directly onto the C-18 cartridges instead of a mixture of 4 volumes of plasma $(15 \mathrm{ml})$ and 1 volume of $5 \times$ concentrated extraction buffer. Norharman concentrations were measured by HPLC with harman as internal standard. The main difference with the earlier method ${ }^{6}$ was that the ion-pair former sodium octyl sulphate was omitted in the eluent, because a fully endcapped 'Zorbax $C 8$ ' column (Dupont) was used. $1.5 \mathrm{fmol}$ norharman could be detected with a signal to noise ratio of 3. With this method plasma concentrations of down to $0.1 \mathrm{nmol} / 1$ norharman could be measured. The mean (SD) plasma norharman concentration of the 23 healthy controls was $0.23(0.22) \mathrm{nmol} / \mathrm{l}$ (range $\leqslant 0 \cdot 1-0 \cdot 7$ ).

The positive identification of norharman was confirmed by liquid chromatography-mass spectrometry (LC-MS) in three different laboratories. In one system, the norharman containing fraction obtained after HPLC was derived with pentafluorobenzoyl chloride and injected onto a RP-6 fully capped 'Phase Sep' reversed-phase column. Norharman was detected on line in the negative chemical ionisation mode with a 'Finnigan', model 4021, mass spectrometer. The other two laboratories used a thermospray LC-MS system (an 'HP 1090' liquid chromatograph coupled to an 'HP 5988A' mass spectrometer and a 'Varian 5000 ' liquid chromatograph coupled to a 'Finnigan MAT TSP' mass spectrometer). Although our findings do not elucidate endogenous formation of norharman in man, we can conclude that this substance is a normal constituent of human blood.
Biological Psychiatry Group,

Departments of Pharmacology

and Psychiatry,

Erasmus University Rotterdam,

Rotterdam, Netherlands

Department of Analytical Research,

Janssen Pharmaceutica,

B-2340 Beerse, Belgıum

DURK FEKKES

M. JORIS SCHOUTEN

LOLKE PEPPLINKHUIZEN

JACQUES BRUINVELS

Department of Analytical Chemistry,

Free University,

Amsterdam

\section{WIM LAUWERS}

\section{UDO A. BRINKMAN}

1. Rommelspacher $\mathrm{H}$, Nanz C, Borbe HO, et al. 1-Methyl- $\beta$-carboline (harmane), a potent endogenous inhibitor of benzodiazepine receptor binding. NatunytSchmeded Arch Pharamacol 1980; 314: 97-100.

2. Nagao $M$, Yahag $T$, Kawachi $T$, et al. Comutagenic action of norharman and harman. Proc Ipn Acad 1977; 53: 95-98.

3. Pawlik M, Rommelspacher H. Dermonstration of a distinct class of high-affinity binding sites for $\left[{ }^{3} \mathrm{H}\right]$ norharman in the rat brain. Eur $\mathcal{F}$ Pharmacol 1988; 147: $163-71$.

4. Greiner B, Rommelspacher $H$. Two metabolic pathways of tetrahydronorharman (tetrahydro- $\beta$-carboline) in rats. Naunyn-Schmiedeb Arch Pharmacol 1984; 325: $349-555$.

5. Schouten MJ, Bruinvels J. Endogenously formed norharman ( $\beta$-carboline) in platelet rich plasma obtained from porphyric rats. Pharmacol Biochem Behav 1986; 24: 1219-23.

6. Schouten MJ, Bruinvels J. High-performance liquid chromatography of tetrahydro$\beta$-carbolines extracted from plasma and platelets. Anal Biochem 1985; 147:401-09. 